\title{
Membongkar Wacana Sertifikasi Dai Menangkal Radikalisme dalam Program Televisi
}

\author{
Abd Munib \\ munib111emdi@gmail.com
}

\begin{abstract}
This scientific work was written to reveal the discourse on dai certification that has been being discussed since 2017. Many media, both print and broadcast-based, have highlighted this discourse. The broadcast media also discussed the discourse so it was natural because the public's consideration saw certification as something important in the midst of the rise of preachers on the pulpit armed with doubtful and doubtful knowledge and conveying religious messages intolerantly and then understanding radicalism. The object of this research is the Prime Talk program which aired on Metro Tv on 19 November 2019 with the title Dai Certification, Counteracting Radicalization using qualitative methods with critical discourse analysis by Van Dijk's model. The author's important notes from the diaphragm presented in this program also serve as data in revealing the discourse Based on the analysis of Van Dijk's model of critical discourse, it shows that the 19 Nomvember 2019 edition of Prime Talk entitled Dai Certification, Warding Radicalization builds five discourses: (1) recently religious messages are often conveyed by speakers whose religious knowledge is shallow so they tend to be extreme; (2) standardization of dai to print frendly dai against the Republic of Indonesia; (3) important dai certification applied throughout Indonesia; (4) Indonesia has been slow in certifying dai; and (5) the security apparatus must be responsive to reduce intolerant conditions.
\end{abstract}

Keywords: discourse analysis, dai certification, radicalism.

\begin{abstract}
Abstrak
Karya ilmiah ini ditulis untuk mengungkap wacana sertifikasi dai yang telah diwacanakan sejak tahun 2017. Banyak media baik yang berbasis cetak maupun siar yang menyorot wacana tersebut. Media siar televisi turut memperbincangkan wacana tersebut sehingga wajar apabila sejumlah masyarakat memandang sertifikasi dai sesuatu yang penting di tengah maraknya penceramah yang naik mimbar dengan bekal pengetahuan keagamaan yang diragukan dan berpotensi menyampaikan pesan-pesan keagamaan dengan intoleran kemudian memicu paham radikalisme. Adapun obyek penelitian ini adalah program Prime Talk yang tayang di Metro Tv pada 19 November 2019 mengangkat tajuk Sertifikasi Dai, Menangkal
\end{abstract}


Radikalisasi dengan menggunakan metodekualitatif dengan analisis wacana kritis model Van Dijk. Penulis mencatat poin penting dari diaolog yang disajikan dalam program ini yang sekaligus menjadi data dalam mengungkap wacana. Berdasarkan analisis wacana kritis model Van Dijk menunjukkan bahwa Prime Talk edisi 19 Nomvember 2019 bertajuk Sertifikasi Dai, Menangkal Radikalisasi membangun lima wacana: (1) akhir-akhir ini pesanpesan agama seringkali disampaikan oleh penceramah-penceramah yang pengetahuan keagamaannya dangkal sehingga cenderung ekstrim; (2) standarisasi dai untuk mencetak dai yang frendly terhadap NKRI; (3) sertifikasi dai penting diberlakukan di seluruh Indonesai; (4) Indonesia sudah lambat dalam sertifikasi dai; dan (5) aparat keamanan harus tanggap untuk menurunkan dai-dai yang intoleran.

Kata Kunci: analisis wacana, sertifikasi dai, radikalisme.

\section{Pendahuluan}

Di Indonesia, program sertifikasi dai muncul sejak tahun 2017 yang diinisiasi oleh Kementerian Agama Republik Indonesia (Kemenag RI). Di mana saat itu, Kemenag masih dipimpin oleh Lukman Hakim dengan masa jabatan 2014-2019. Sebagai pengganti jabatan kemenag sejak Oktober 2019, Fachrul Razi kembali menggulirkan program sertifikasi dai tersebut karena dipandang penting kususnya dalam merawat Negara Kesatuan Republik Indonesia (NKRI). Diskursus tentang mengemukanya sertifikasi dai dimulai dengan adanya dugaan pemerintah yang mengait-kaitkan bahwa paham-paham radikalisme yang diserap oleh masyarakat berkelindan dengan pemahaman keagamaan yang disampaikan di mimbar-mimbar ceramah oleh juru dakwah.

Kesakralan dan kemurnian Islam sebagai Agama damai dan menyejukkan akan terbantahkan apabila pesan-pesan ajarannya disampaikan secara sarkasme. Justru Islam menganjurkan penggunaan perkataan-perkataan yang baik serta bijaksana dalam segala aspek dialog. Tuduhan mensyiarkan Islam dengan cara-cara yang kasar dan anti-toleran sungguh tidak benar adanya. Memang betul bahwa para sahabat telah berbaiat untuk mengorbankan jiwa-raganya jika sewaktu-waktu terjadi keadaan yang amat genting. Namun demikian, meraka sepakat untuk tetap mengedapakan kedamaian. Sejatinya, dakwah menjadi sebuah penopang utama dalam mengkomunikasikan pesan-pesan agama karena melalui dakwah pesan-pesan agama akan tersampaikan. Dakwah disampaikan dengan cara-cara simpatik, bijaksana dan lebih humanis. Konsep dakwah dengan pendekatan sosial dan budaya yang diterima oleh masyarakat luas, memperhatikan ruang dan waktu, topik-topik aktual, menyentuh kebutuhan dasar mad'u dan isu-isu terkini dalam masyarakat. ${ }^{1}$

Begitulah Agama Islam adanya sehingga wajar apabila di kalangan kritikus Eropa yang mengerti terhadap ajaran Islam sebagaimana dikutip oleh Maulana Muhammad Ali menyuarakan bahwa Nabi Muhammad SAW. tidak perrnah

${ }^{1}$ Efa Rubawati, "Media Baru: Tantangan Dan Peluang Dakwah," Jurnal Studi Komunikasi Vol. 2. Maret 2018. 
menggunakan luapan kekerasan dalam menyebarkan Ajaran Islam.2Dalam Islam, perdamaian merupakan kunci menjalin hubungan yang baik antar manusia. Dengan pernadamaian manusia akan hidup dengan aman, punuh ketenagan, dan penuh kebahagiaan. ${ }^{3}$ Maka sudah seharusnya, dai-dai yang menyampaikan pesan-pesan Agama mempraktikkannya dengan cara-cara menebar kedaiamaian. Sebab jika tidak, maka Agama Islam alih-alih meneduhkan justru pesan-pesan Agama berpotensi dijadikan alat untuk saling menyalahkan. Konsekuensinya, pertikaian berkelanjutan tidak bisa dielakkan lalu Agama Islam terus-menerus dituduh sebagai paham radikalisme. Padahal, radikalis dalam menyeberakan Agama Islam sebetulnya dimulai dari memahami Agama yang cenderung banal dan dangkal. ${ }^{4}$

Situasi keagamaan semacam tersebut diperunyam dengan kemunculan daidai baru yang sangat bebas dalam menyampaikan pesan-pesan keagamaan. Kemunculan dai-dai baru tentu menawarkan angin segar bagi pemahaman keagamaan masyarakat sekaligus menjadi tantangan tersendiri karena pesan Agama berpotensi disampaikan dengan pemahaman ekstrem. Guna mengantisipasi terjadinya penyampaian pesan keagamaan yang ekstrem alias intoleran oleh dai maka dai disyaratkan memiliki tiga pemahaman: keagamaan, kebangsaan, dan metode dakwah.Program sertifikasi dai menuai kontroversi tersendiri di kalangan publik di Indonesia. Ada yang mendukung dengan program sertifikasi dengan alasan agar pesan-pesan keagamaan di sampaikan oleh penceramah-penceramah yang memang memiliki kompetensi keagamaan.

Namun kompetensi keagamaan saja tidak cukup sehingga harus diimbangi dengan pengetahuan tentang metode dan pemahaman kebangsaan. Ada pula yang menolak terhadap program sertifikasi dai dengan alasan masyarakat sudah pandai dan cerdas dalam menentukan penceramah yang memang sudah kompeten. Alasan lain terhadap penolakan sertfikasi dai dikhawatirkan Negara terlalu ikut campur dalam hal keagamaan keagamaan masyarakat sebab melalui sertifikasi dai, Negara dapat mengontrol konten-konten keagamaan yang akan disampaikan oleh penceramah. ${ }^{5}$ Maka karena itu, walaupun sertifikasi dai akan dilaksanakan jangan

\footnotetext{
${ }^{2}$ Maulana Muhammad Ali, Islamologi, (Jakarta: Darul Kutub Islamiyah, 1997). Hlm. 565.

${ }^{3}$ Arina Rahmatika and Ninda Khoirullina, "Upaya Meneguhkan Islam Rahmatan Lil'alamin Melalui Majalah Bangkit," Jurnal Dakwah Dan Komunikasi Vol. 5 no. 2, 2020.

${ }^{4}$ Jika tidak bukan mustahil situasi ini dapat berpotensi mimbar-mimbar keagamaan dialih-fungsikan menjadi ruang dan tempat menyebarkan paham radikal sehingga jamaah yang datang justru bukan mendapatkan keteduhan rohani melainkan keriuhan. Abd. Munib, "Framing Media Atas Pemberitaan Sertifikasi Dai," Jurnal Peurawi Vol. 3 No. 2. Tahun 2020 .

${ }^{5}$ Dalam konteks ini, David G. Bromley melihat salah satu fenomena yang mungkin muncul, yakni fenomena quasi-religious corporations, yakni korporasi yang menjanjikan reintegrasi antara pekerjaan, politik, keluarga, komunitas dan agama melalui pembentukan bisnis yang saling berhubungan dengan jaringan sosial dan diperkuat secara simbolik dengan nasionalisme dan tujuan transenden. David G. Bromley, "QuasiReligious Corporations: A new integration of religion and capitalism?", dalam Richard
} 
sampai wacana tersebut menjalar pada tendensi untuk melakukan komoditas terhadap pesan-pesan Agama. ${ }^{6}$

\section{Wacana Sertifikasi Dai}

Wacana menurut Althusser, sebagaimana dikutip Faruk, sarat dengan muatan ideologi. ${ }^{7}$ Althusser mengemukakan dua tesis mengenai ideologi: pertama, ideologi merepresentaasikan hubungana-hubungan imajener antara individu dengan kondisi-kondisi eksistensinya yang nyata. Dunia yang dubangun oleh ideologi tidak sesuai dengan kenyataan cenderung menyerupai ilusi. Meskipun demikian, dunia itu membuat ilusi ke arah realitas dan hanya dibutuhkan interpretasi untuk realitas yang sebenarnya di balik representasi imajener; kedua, ideologi memiliki suatu eksistensi material. Gagasan yang membangun ideologi tidak bersifat ideal atau spiritual melainkan mempunyai eksistensi material. Ideologi selalu hadir dalam suatu aparatus dan praktik atau praktik-praktiknya.

Hal ini akan mengurangi subyektifitas bahwa seorang dai sudah memenuhi kapasitas atau belum. Karena itu, sertifikasi dai tidak dapat menjadi stempel bahwa dai akan menjadi sebuah profesi dengan bayaran sesuai kualifikasi jenjang sertifikasi yang diperoleh. Jangan sampai amanat mulia menyampaikan ajaran Islam terjebak pada komodifikasi. ${ }^{8}$ Ini pulalah yang akan merendahkan nilai dakwah yang dilakukan oleh para dai. Menjadi pendakwah merupakan panggilan hati yang muncul di masyarakat. Yang memberi pengakuan atas kompetensi dai selama ini juga masyarakat, apakah seorang dai memiliki pengaruh di tingkat kampung, kabupaten atau memilki jangkauan nasional.

Bahasa yang digunakan media seperti sertifikasi dai dapat menciptakan realitas tertentu kepada khalayak. Hal tersebut didasarkan pada pendapat yang dikemukakan oleh Burke, dalam Language as Symbolic Action sebagaimana dikutip Aris Badara, yang menyatakan bahwa kata-kata tertentu tidak hanya memfokuskan perhatian khalayak pada masalah tertentu tetapi juga membatasi persepsi dan mengarahkan khalayak pada cara berpikir dan keyakinan tertentu. Dengan kata lain, kata-kata yang digunakan media dapat membatassi seseorang melihat perspektif lain, menyediakan aspek tertentu dari suatu peristiwa dan mengarahkannya untuk memahami suatu peristiwa. ${ }^{9}$ Dalam kaitannya sertifikasi dai bahwa diksi sertifikasi

H. Roberts (ed.), Religion and the Transformations of Capitalism: Comparative Approaches, (London and New York: Routledge, 1995). 135.

${ }^{6}$ Pesan dakwah dikomodifikasi menjadi narasi. Miftahul Huda, "Komodifikasi

Pesan Dakwah Pada Iklan Pertamina Versi Tabungan Terbaik Di Televisi," Jurnal Dakwah Dan Komunikasi Vol. 3 No. 2, 2018.

7 Faruk HT, Analisis Wacana: Dari Linguistik Sampai Dekonstruksi, (Yogyakarta: Kanal, 2002). 138-139.

${ }^{8}$ Ridwan Rustandi, "Analisis Wacana Kritis Komodifikasi Dai dalam Program Televisi,"Communicatus Volume 2 Nomor 2 Tahun 2018.

9 Badara, Arif, Analisis Wacana: Teori Metode, dan Penerapannya Pada Wacana Media, (Jakarta: Kencana, 2012). 57. 
adalah merujuk pada suatu surat keterangan yang menunjukkan profesionalis dalam mempraktikkan profesinya. ${ }^{10}$

Profesionalisme berasal dari kata "profess" yang menunjukkan pada suatu pekerjaan atau jabatan yang menuntut keahlian, tanggung jawab dan kesetiaan terhadap profesi. Suatu profesi secara teoretik tidak bisa dilakukan oleh sembarang orang yang tidak dilatih atau dipersiapkan untuk itu. ${ }^{11}$ Menurut Sagala profesionalisme tidak dapat dilakukan atas dasar perasaan, kemauan, pendapat, atau semacamnya, tetapi benar-benar dilandasi oleh pengetahuan semacam akademik. ${ }^{12}$ Dalam masa reformasi ini upaya pembinaan untuk meningkatkan kehidupan keagamaan masyarakat memerlukan strategi yang tepat sasaran dan menyentuh aspek kesadaran masyarakat dalam menjalankan dan menyampaikan perintah Agama. Hal ini penting mengingat masyarakat sekarang berada dalam situasi krisis kepercayaan. Masyarakat sekarang sudah jenuh dengan problematika kehidupan mereka yang multi dimensional. Kehadiran ulama yang bisa membawa dan mengarahkan masyarakat kearah kedamain, ketentraman batin dalam menghadapi berbagai krisis kehidupan dan keluar dari persoalan tersebut sangat diharapkan. ${ }^{13}$ Barangkali inilah mengapa Amin Abdullah menyatakan bahwa perlu sikap kehatian bagi para tokoh agama memasuki wilayah kekuasaan jangan sampai terjebak dalam kesewenangan atau arogansi kekuasaaan. ${ }^{14}$

\section{Metode Analisis Vandijk}

Metode yang digunakan dalam penelitin ini adalah Analisis Wacana Kritis (CriticalDiscourseAnalysis (CDA) yang dikembangkan oleh Teun A.van Dijk, yang sering disebut sebagai "kognisi sosial". Menurut van Dijk, penelitian atas wacana tidak cukup pada teks, tetapi juga harus dilihat praktik produksinya. Eriyanto menggambarkan model dari analisis van Dijk sebagai berikut: ${ }^{15}$

${ }^{10}$ Aturan normatif kompetensi profesional dan etika professional menekankan pada fungsi, prioritas sistemik dalam tindakan profesional. Keduanya memiliki andil dalam melakukan diferensiasi identitas personal, termasuk identitas kelompok, dari apa yang dilakukan oleh sistem institusional; dan menekan independensi relatif kedua sistem sosial dan individu yang terlibat di dalamnya. Moch. Fakhroji, "Komodifikasi Agama Sebagai Masalah Dakwah,” Jurnal Ilmu Dakwah Vol. 5 No. 16 Juli-Desember 2010.

${ }^{11}$ D. Supriadi, Mengangkat Citra Dan Martabat Guru, (Yogyakarta: Adicitra Karya Nusa, 2000). 9.

${ }^{12}$ S. Sagala, Administrasi Pendidikan Kontemporer, (Bandung: Alfabeta, 2006). 195-199.

${ }^{13}$ Saipul Annur, "Respon Masyarakat Terhadap Sertifikasi Ulama Di Kota Palembang," Medina-Te Vol. 18 No. 1 Juni 2018 (n.d.).

${ }^{14}$ Amin Abdullah, Etika dan Dialog Antar Agama: Perspektif Islam, (Yogyakarta: Dian/Interfide, 1993. 46.

${ }^{15}$ Eriyanto, Analisis wacana: pengantar analisis teks media, (Yogyakarta: LkiS, 2012). 222-225. 


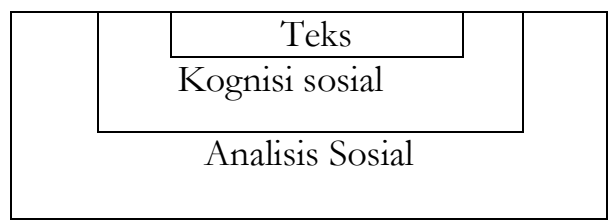

Model yang dikembangkan van Dijk tidak hanya memandang struktur mikro (teks) dan struktur makro (konteks), tetapi juga struktur meso yang menghubungkan teks dan konteks, yaitu kognisi sosial. Dimensi teks melihat bagaimana struktur teks dan strategi wacana yang dipakai untuk menegaskan suatu tema tertentu. Kemudian dimensi kognisi sosial mempunyai dua arti yakni, kognisi sosial menunjukkan bagaimana proses teks diproduksi wartawan atau media sendiri serta kognisi sosial menggambarkan nilai-nilai masyarakat menyebar dan diserap oleh wartawan yang pada gilirannya digunakan untuk membuat teks berita. Dimensi terakhir yaitu konteks sosial. Dimensi ini mempelajari bangunan wacana yang berkembang dalam masyarakat mengenai suatu masalah tertentu.

Untuk menganalisis wacana, Van Dijk membagi teknik analisis ke dalam tiga dimensi analisis, yaitu struktur teks, kognisi sosial, dan analisis sosial:16Pertama, struktur Teks terdiri dari: (a) Topik di mana topik berita bisa disimpulkan setelah tuntas membaca, mendengar, atau menonton berita tersebut. Gagasan penting van Dijk, wacana umumnya dibentuk dalam tata aturan umum. Teks tidak hanya didefiniskan tetapi suatu pandangan umum yang koheren, yaitu bagian-bagian dalam teks menunjuk pada satu titik gagasan umum, dan bagian-bagian tersebut saling mendukung satu sama lain untuk menggambarkan topik umum tersebut; (b) Skematik, arti penting dari skematik adalah strategi wartawan untuk mendukung teori tertentu yang ingin disampaikan dengan menyusun bagian-bagian dengan urutan tertentu. Skematik memberikan tekanan bagian mana yang didahulukan dan bagian mana yang bisa kemudian sebagai strategi menyembunyikan informasi penting.

Teks atau wacana pada umumnya mempunyai skema atau alur dari pendahuluan sampai akhir. Alur tersebut menunjukkan bagaimana bagian-bagian dalam teks disusun dan diurutkan hingga membentuk kesatuan arti; (c) Semantik atau makna yang ingin ditekankan dalam teks dapat dilihat dari beberapa hal seperti latar, detil, maksud, dan praanggapan. Latar, detil dan maksud berhubungan dengan informasi mana yang ditekankan dan mendapatkan porsi lebih banyak. Sementara itu elemen praanggapan merupakan pernyataan yang digunakan untuk mendukung makna suatu teks; (d). Sintaksis berhubungan dengan bagaimana kalimat yang dipilih. Sintaksis dapat dilihat dari koherensi, pengingkaran, bentuk kalimat, dan kata ganti; (e) Stilistik berhubungan dengan bagaimana pilihan kata yang digunakan dalam teks berita. Elemen stilistik dikenal dengan leksikon. Pada dasarnya leksikon menandakan bagaimana seseorang melakukan pemilihan kata dari sekian banyak pilihan yang ada; (f) Retoris berhubungan dengan bagaimana dan dengan cara apa penekanan dilakukan. Retoris dapat dilihat dari penggunaan grafis, metafora serta

\footnotetext{
${ }^{16}$ Eriyanto, 229-274.
} 
ekspresi. Grafis melihat penggunaan grafik, gambar, atau tabel untuk mendukung arti penting suatu pesan. Elemen grafik memberikan efek kognitif, dalam arti ia mengontrol perhatian dan ketertarikan secara intensif dan menunjukkan bahwa informasi tersebut penting dan harus diperhatikan.

Kedua, kognisi sosial. Kognisi sosial melihat bagaimana suatu teks diproduksi. Kognisi sosial berkaitan dengan kesadaran mental wartawan yang membentuk teks tersebut. Van Dijk berangkat dari gagasan bahwa teks sendiri tidak mempunyai makna, melainkan diberikan oleh proses kesadaran mental dari pemakai bahasa. Wartawan tidak dipandang sebagai individu yang netral, tetapi individu yang mempunyai bermacam-macam nilai, pengalaman, dan pengaruh ideologi yang didapat dari kehidupannya. Van Dijk menyebutkan bahwa peristiwa dipahami dan dimengerti berdasarkan skema. Skema dikonseptualisasikan sebagai struktur mental di mana di dalamnya tercakup bagaimana kita memandang manusia, peranan sosial, dan peristiwa. Ada beberapa macam skema atau model yang dapat digambarkan: (a) Skema person, skema ini menggambarkan bagaimana seseorang menggambarkan dan memandang orang lain. Misalnya bagaimana wartawan Islam memandang dan memahami orang Kristen akan mempengaruhi teks berita yang ia tulis; (b) Skema diri di mana skema ini berhubungan dengan bagaimana diri sendiri dipandang, dipahami, dam digambarkan oleh seseorang; (c) Skema peran yang berhubungan dengan bagaimana seseorang memandang dan menggambarkan peranan dan posisi yang ditempati seseorang dalam masyarakat; (d). Skema peristiwa, skema ini barangkali paling banyak dipakai, karena hampir setiap hari kita selalu melihat dan mendengar peristiwa. Dan setiap peristiwa selalu ditafsirkan dan dimaknai dalam skema tertentu. Umumnya, skema peristiwa inilah yang paling banyak dipakai oleh wartawan.

Model ini sangat berkaitan dengan representasi sosial, yakni bagaimana pandangan, kepercayaan, dan prasangka yang berkembang dalam masyarrakat. Wartawan hidup di antara keyakinan dan pandangan masyarakat tersebut. Meskipun demikian, bagaimana keyakinan tersebut mempengaruhi wartawan akan dipengaruhi oleh pengalaman, memori, dan interpretasi wartawan. Bagi van Dijk, kognisi sosial terutama berhubungan dengan proses produksi berita. Produksi berita sebagian besar dan terutama terjadi dalam kognisi seorang wartawan. Oleh karena itu pertanyaan utama yang diajukan oleh van Dijk adalah bagaimana wartawan mendengar dan membaca peristiwa, bagaimana peristiwa tersebut dimengerti, dimaknai, dan ditampilkan dalam pikiran. Bagaimana peristiwa tersebut difokuskan, diseleksi, dan disimpulkan dalam keseluruhan proses produksi berita? Bagaimana informasi yang telah dipunyai dan dimiliki oleh wartawan tersebut dipakai dalam memproduksi berita.

Ketiga, analisis sosial. Titik penting dari analisis ini adalah untuk menunjukkan bagaimana makna yang dihayati bersama, kekuasaan sosial diproduksi lewat praktik diskursus dan legitimasi. Menurut van Dijk, ada dua poin yang penting: kekuasaan dan akses: (a) Praktik kekuasaan. Van Dijk mendefinisikan kekuasaan sebagai kepemilikan suatu kelompok (atau anggotanya) yang mengontrol kelompok lain. Kekuasaan ini umumnya didasarkan pada kepemilikan atau sumber-sumber yang bernilai seperti uang, status dan pengetahuan. Kekuasaan tidak hanya diperoleh melalui kontrol fisik, tetapi juga melalui tidakan persuasif dengan jalan 
mempengaruhi kondisi mental seperti kepercayaan, sikap, dan pengetahuan. Analisis wacanamemberikan perhatian kepada dominasi. Dominasi direproduksi oleh pemberian akses yang khusus pada satu kelompok dibandingkan kelompok lain. Ia juga memberi perhatian atas proses produksi lewat legitimasi melalui bentuk kontrol pikiran; (b). Akses mempengaruhi wacana. Analisis wacana memberikan perhatian pada akses, bagaimana akses di antara masing-masing kelompok dalam masyarakat. Kelompok elit mempunyai akses yang lebih besar dibandingkan dengan kelompok yang tidak berkuasa. Oleh karena itu, mereka yang lebih berkuasa mempunyai kesempatan lebih besar untuk mempunyai akses pada media, dan kesempatan lebih besar untuk mempengaruhi kesadaran khalayak melalui kontrol atas topik dan isi wacana.

\section{Hasil Penelitian dan Pembahasan}

Perogram Prime Talk pada 19 November 2019 mengangkat teman "Sertifikasi Dai, Menangkal Radikalisme. Format acara ini dibuka dengan sajian informasi singkat tentang fenomena dai di Indonesia oleh Zilvia Iskandar lalu kemudian mengajukan pertanyaan pada narasumber yang hadir. Namun demikian, acara talk show ini dijeda dengan iklan sebelum akhirnya program selesai. Acara yang dipandu oleh Zilvia Iskandar tersebut mendatangkan dua narasumber. Pertama, Maman Imanulhaq (MI) yang dilabeli sebagai anggota DPR RI Komisi VIII dari praksi PKB. Secara akademik Maman Imanulhaq mengenyam akademik pendidikan dasar di SDN CImalaka III dan melanjukan pendidikan MTs-MA Baitul Arqom Bandung Barat sambil mondok di Pesantren Baitul Arqom hingga tahun 1990. Program sarjana Maman ditempuh di STAI Majalengka dan pernahmengenyam sarjana di Fakultas Hukum, Universsitas Darul Ulum Jombang. Kualitas keaagamaan yang dimiliki mengantarnya menjadi penceramah yang kerap tampil di layaar Tv untuk mensyiarkan pesan-pesan Agama Islam. Kedua, Masduki Baidawi (MB) selaku Ketua Bidang Komunikasi Dan Informasi MUI. Dia mengenyam pendidikan di Madrasah Ibtidaiyah Miftahul Jannah, MTs di Pesantren Sidogiri, dan MA di Pesantren Salafiyah dan menemupuh pendidikan sarjana di IAIN Sunan Ampel Surabaya. Kualitas keilmuan mengantarkan dirinya menduduki wakil sekjen PBNU pada 1999-2004. Atas dasar inilah, pemilihan dua narasumber dalam program Prime Talk layak untuk dikaji.

Guna keteraturan penulisan dalam karya ilmiah ini, penulis mencatat poinpoin penting dialog dari menit pertama ke menit berikutnya sampai akhir yang kemudian digunakan untuk mengeksplorasi temuan-temuan wacana yang ingin dibangun. Selain itu, penulis mengakui tidak mencatat semua isi dialog selama program ini tayang sehingga mengesampingkan dialog lain agar penulisan serasi dan tidak tumpang tindih. Secara skematik, data-data Prime Talk "Sertifikasi Dai, Melawan Radikalisasi" dapat disajikan dalam tabel di bawah ini: 


\begin{tabular}{|c|c|c|}
\hline Waktu & Segmen & Keterangan \\
\hline $\begin{array}{l}00: 50- \\
01: 33\end{array}$ & Pembukaan Prime Talk & $\begin{array}{l}\text { Zilvia Iskandar memberi } \\
\text { pernyataan bahwa dai harus } \\
\text { menyebarkan materi dakwah yang } \\
\text { moderat yakni, tidak ekstrem kanan } \\
\text { dan juga tidak ekstrem kiri. } \\
\text { Pembukaan ini juga digunakan oleh } \\
\text { Zilvia untuk memperkenalkan dua } \\
\text { narasumber yang dihadirkan dalam } \\
\text { acara tersebut yakni, Maman } \\
\text { Imanulhaq yang dilabeli sebagai } \\
\text { anggota DPR RI Komisi VIII dari } \\
\text { praksi PKB dan Masduki Baidawi } \\
\text { selaku Ketua Bidang Komunikasi } \\
\text { Dan Informasi MUI. }\end{array}$ \\
\hline $\begin{array}{l}03: 50- \\
10: 20\end{array}$ & Sertifikasi dai sebagai solusi & $\begin{array}{l}\text { Sertifikasi dai untuk mencetak dai- } \\
\text { dai yang freandly terhadap NKRI } \\
\text { melalui standar tes; kedalaman } \\
\text { dalam persoalan agama; bisa } \\
\text { mengkontekskan keagamaannya } \\
\text { dengan nilai-nilai negara }\end{array}$ \\
\hline $\begin{array}{l}10: 25- \\
15: 00\end{array}$ & $\begin{array}{lrr}\text { Seritikasi dai } & \text { akan } \\
\text { diberlakukan di } & \text { seluruh } \\
\text { daerah Indonesia } & \end{array}$ & $\begin{array}{l}\text { Dukungan dari organisasi } \\
\text { keagamaan seperti } \mathrm{NU} \text {, } \\
\text { Muhammadiyah, dan persis sangat } \\
\text { dibutuhkan untuk melaksanakan } \\
\text { standarisasi }\end{array}$ \\
\hline $\begin{array}{l}15: 05- \\
18: 10\end{array}$ & $\begin{array}{l}\text { Indonesia terlambat } \\
\text { melakukan standarisasi dai }\end{array}$ & $\begin{array}{l}\text { Prime Talk menjadikan Arab Saudi } \\
\text { dan Malaysia sebagai contoh negara } \\
\text { yang patut dicontoh karena telah } \\
\text { lebih dahulu melakukan standarisasi } \\
\text { dai. Atas nama demokrasi, } \\
\text { Indonesia sudah kebablasan } \\
\text { akibatnya intoleran }\end{array}$ \\
\hline $\begin{array}{l}18: 15- \\
19: 59\end{array}$ & $\begin{array}{l}\text { Dai bersertifikat MUI diawasi } \\
\text { lagi }\end{array}$ & $\begin{array}{l}\text { Masyarakat melapor dan aparat } \\
\text { harus bergerak cepat kalau ada } \\
\text { pengajian yang tiba-tiba hate speech } \\
\text { dan provokasi }\end{array}$ \\
\hline
\end{tabular}


Dari durasi waktu dalam kerangka skematik di atas terlihat bahwa Prime Talk Sertifikasi Dai, Melawan Radikalisasi fokus pada bagaimana agar para penceramah tergerak untuk mengingukuti program sertifikasi dai oleh (sekitar 20 menit dari total siaran 30 menit).

\section{Anailisis dan Interpretasi}

Temuan data menunjukkan bahwa secara tematik Prime Talk episode Sertifikasi Dai, Melawan Radikalisasi yaitu untuk melawan gerakan ekstremis yang cenderung tekstual dalam memahami ajaran-ajaran agama. Ini juga yang menunjukkan bahwa Prime Talk sangat mendukung terhadap langkah Majelis Ulama Indonesia (MUI) untuk menjalankan program sertifikasi dai. Dorongan ini terlihat dari wacana yang dibangun dalam diskursus pada program acara Prime Talk ini. Dalam perjalanannya, kesatuan bangsa Indonesia memang sering mendapat ancaman. Ekstrim dan berlebih-lebihan dalam melaksanakan agama adalah faktor terbesar mencuatnya perpecahan. Berlebih-lebihan yang dimaksud di sini adalah mempersulit diri sendiri dan orang lain dalam melaksanakan hukum-hukum syariat, atau dalam bersikap terhadap orang lain atau bermuaamalah tanpa mengindahkan etika-etika syariat dan kaidah-kaidah agama. Karena sesunguhnya Islam tegak di atas pelaksanaan hukum-hukum Islam secara menyeluruh dengan memperhatikan sisi kemudahan dan menolak kesulitan, memberikan keluasaan, mengambil dispensasi secara proposional, berbaik sangka kepada orang lain, ramah, pemaaf dan halus dalam memberi peringatan. Inilah prinsip-prinsip dasar. Keluar dari prinsip-prinsip tersebut tanpa maslahat yang pasti dan dibenarkan oleh ahli ilmu merupakan hal-hal dalam tindakan ekstrim yang dilarang dan harus dijauhi.

Untuk mengantisipasi gerakan ekstrimis dengan sertifikasi yang di lakukan MUI, Prime Talk membangun narasi-narasi sebagai berikut:

1. Pesan-pesan agama disampaikan oleh orang yang pemahaman keagamaannya dangkal

Narasi-narasi tentang pesan agama yang disampaikan oleh dai-dai dengan pemahaman keagamaan yang dangkal telah dimunculkan sejak awal:

a. "Dai harus menyebarkan materi dakwah yang moderat yakni, tidak ekstrem kanan dan juga tidak ekstrem kiri."

b. "Para dai benar-benar tidak menyerukan pesan intoleran bahkan menyerukan anti NKRI."

Zilvia menekankan para dai yang berkiprah di tengah-tengah masyarakat harus moderat dalam berdakwah jangan sampai pesan-pesan yang disampaikan tidak menyerukan pesan intoleran apalagi sampai mengancam NKRI. Dengan begitu sertifikasi dai yang dijalankan oleh MUI dapat mengantisipasi hal-hal yang memicu kontroversial karena pada awalnya kontroversi tentang pemahaman terhadap keagamaan seringkali diawali oleh pemahaman terhadap agama yang cenderung dangkal dan banal. Hingga kemudian disematkanlah gelar ustadz atau ustadzah di bahunya. Naasnya, tidak sedikit dari mereka yang tidak memiliki latar belakang pengatahuan keislaman yang mendalam Karena biasanya ada juga selebriti yang banting setir menjadi ustadz atau ustadzah meski baru 'sedikit' belajar tentang Islam dan segala disiplin keilmuannya. 
2. Mencetak dai-dai yang frendly terhadap NKRI

Pada menit 03:50-10:20 Prime Talk membangun narasi dai bersahabat dengan NKRI dimana yang dimaksud dengan dai bersahabat adala, "Dai-dai tidak menyebarkan materi ceramah yang intoleran babkan bisa merusak NKRI," sebagaimana dijelaskan Masduki Baidawi selaku Ketua Bidang Komunikasi Dan Informasi MUI dalam Prime Talk. Selanjutnya, narasi-narasi yang dibangun menekankan agar menginginkan sertifikasi dai ini diwajibkan bukan sekadar disarankan bagi para dai yang hendak berceramah di masjid-masjid instansi pemerintah.

Banyaknya para penceramah di Indonesia menjadikan medan dakwah mereka juga berbeda-beda. Ada yang berdakwah di surau, masjid, majelis taklim, bahkan hingga ada yang berdakwah di televisi, radio ataupun media sosial seperti youtube. Ada juga gelar ustadz atau ustadzah tersebut disematkan oleh televisi tertentu - meski tidak terlalu menguasai ilmu-ilmu keislaman tetapi menghiburuntuk mengejar rating. Meski demikian, ada juga yang dakwah di televisi atau media sosial tersebut adalah orang yang benar-benar mendalami dan menekuni Islam karena mereka memang belajar tentang Islam dan disiplin ilmu-ilmu keislaman selama berpuluh-puluh tahun. Kehadiran ustadz atau ustadzah di televisi atau media sosial tersebut tidak jarang membuat masyarakat heboh karena materi-materi yang mereka sampaikan begitu kontroversial. Bahwa NKRI adalah sebuah kesepakatan dan kita berkomitmen untuk hidup di dalam bingkai NKRI. Dengan begitu, dai memahami konteks pembicaraan dan wawasan tentang lingkungan dan masyarakat sehingga apa yang disampaikan bisa menjadi inspirasi.

3. Sertifikasi dai akan diberlakukan di seluruh Indonesai

Pada menit-menit awal, Prime Talk menunjukkan bahwa sertifikasi dai akan di berlakukan bagi para para dai-dai yang hendak berceramah di masjidmasjid instansi pemerintahan namu pada menit 10:25-15:00 narasi itu sertifikasi dai berlanjut untuk diberlakukan di seluruh Indonesia. Hal ini membuktikan bahwa selalu ada wacana di balik wacana maka perlu dukungan atau pembelakaan untuk kemudian wacana itu diterima dengan tangan terbuka oleh masyarakat. Untuk mencapai keberhasilan wacana sertifikasi dai oleh karena itu, Komisi Dakwah Majelis Ulama Indonesia akan bekerja sama dengan Kemenag, Universitas Islam Negeri, Ormas-ormas Islam seperti NU, Muhammadiyah, dan lainnya untuk melakukan standarisasi dai. Hal itu dilakukan agar materi dakwah yang disampaikan para dai, ustadz, dan ustadzah tersebut bisa dipertanggungjawabkan dan kredibel. Prime Talk membangun bebrbagai narasi yang pada akhirnya sebagai cara untuk berkoordinasi dengan pihak terkait sehingga ke depan orang yang ceramah di televisi atau publik itu harus mendapatkan rekomendasi dari lembaga yang kredibel seperti Kemenag, UIN, MUI, NU, Muhammadiyah, dan lainnya. Dengan adanya rekomendasi itulah maka pertanggungjawaban dari suatu lembaga yang merekomendasi atau mensertifikasi akan terlihat. Apalagi sekarang banyak terjadi kesalahpahaman dan sensasi itu biasanya dari dai yang tidak jelas afiliasi paham keagamannya. Berkaitan dengan makna tersebut, Prime Talk menjelaskan alasannya tentang 
wacana ini bahwa standarisasi ini adalah bentuk aspirasi sebagian ormas Islam untuk meminimalisir ulama-ulama yang dalam khutbahnya keras dan vocal dalam menyuarakan kritikannya terhadap pemerintah yang dianggap bisa menimbulkan gesekan di tengah masyarakat agar tidak setiap orang bisa naik mimbar berceramah dengan pemahaman keagamaannya dangkal.

4. Indonesia sudah lambat dalam sertifikasi dai

Prime Talk menjadikan Arab Saudi dan Malaysia sebagai contoh negara yang patut dicontoh karena telah lebih dahulu melakukan standarisasi dai. Sehingga pada menit 15:05- 18:10 Atas nama demokrasi, Indonesia sudah kebablasan akibatnya intoleran. Di dalam mempermulus wacana umumnya para pelaku wacana memang mencari-cari kemiripan-kemiripan yang pernah terjadi sebelumnya karena sebagaimana diungkap Van Dijk bahwa wacana tidak lahir seketika yakni, dengan peristiwa-peristiwa yang pernah ada sebelumnya bahkan di tempat lain. "Atas nama demokrasi, Indonesia sudah kebablasan (tidak melakukan sertifikasi dai) akibatnya intoleran," kata Masduki Baidawi yang kemudian didukung oleh Maman Imanulhaq bahwa "Waktu saya mimpin Lembaga Dakwah PBNU, saya datang ke beberapa negara Eropa ternyata yang ditanyakan pertama, tolong Kang Maman mana CV dai ini, dia spsifik di bidang apa?"

Dalam Prime Talk ini ditunjukkan bahwa sebetulnya sertifikasi dai ingin memperbaiki kualitasnya dari pada mengekang siapa yang berhak untuk ceramah dan siapa yang tidak berhak untuk ceramah. Selama ini kita masih bertumpu kepada kekuatan masyarakat. Artinya, masyarakat yang mengundang, masyarakat yang membayar, dan masyarakat yang punya acara. Itu berbeda dengan negara tetangga kita seperti Malaysia atau Brunei. Orang yang menjadi dai itu adalah atas biaya negara. Yang distandarisasi apa saja nantinya? Pertama, kita akan melakukan standar dasar seorang dai yaitu kemampuan orang di bidang agama. Apakah dia sudah layak menyampaikan ilmu itu di publik. Ada standar yang memang untuk hanya mengajar seperti mengajar Iqra, mengajar tajwid, mengajar tafsir. Kita ada standar dasar bahwa orang yang berbicara di publik itu minimal bacaan Al-Qur'annya bagus, mengerti agama dengan baik. Kalau dia ceramah di televisi, pertama dia harus mengetahui tentang paham-paham keagamaan di Indonesia. Jadi dia tidak nabrak-nabrak ke yang lain. Kedua, mengetahui perbedaan-perbedaan ulama. Jika para ustadz tersebut menguasai sesuatu yang khilafiyah maka mereka bisa memberikan pemahaman yang menyeluruh kepada umat. Ketiga, dia paham hubungan antara agama dan negara termasuk pilihan Pancasila ini sebagai dasar negara sehingga dia tidak menyoroti kesepakatan yang sudah disepakati.

5. Aparat keamanan harus tanggap

Penyusunan kata dan struktur kalimat yang digunakan di sini sangat jelas kalau orang yang melakukan yang macam-macam dan mengarah kepada kriminal, dia akan diproses secara hukum. Pada menit 18:15-19:59 Prime Talk memainkan kontrol. Maksudnya adalah walaupun ada dai yang sudah lolos dan mendapat sertifikat dari MUI tidak serta-merta akan lepas dari pengawasan tetapi akan terus dipantau dengan melibatkan masyarakat sehingga masyarakat 
disarankan untuk tidak diam ketika melihat dai-dai yang masih menyampaikan pesan-pesan intoleran. Sebagai bukti bahwa masyarakat telah melakukan pengawasan, Maman Imanulhaq menyampakain dalam Prime Talk untuk melapor kepada aparat keamanan, "Masyarakat boleh melapor kepada kepolisisan dan Polisi berhak menurunkan dai tersebut." Adapun Baidawi sebelum menutup pembicaraannya hendak mengajak seluruh dai-dai dari berbagai kalangan untuk mengikuti program standarisasai ini bahkan dai yang tidak jelas rekam jejaknya bisa mendapat sertifikat dengan standar MUI melalui layanan kursus singkat yang di dalamnya ada kaderisasi dakwah agar pencermah ramah sebagai dai. Standarisasi dai diperlukan untuk mengantisipasi radikalisme dan tahapan orang berbuat radikal dimulai dari puritanisme, radikalisme, lalu kemudian radikalisme.

Adapun titik penting dari analisis sosial dalam analisis wacana Van Dijk adalah untuk menunjukkan bagaimana makna yang dihayati bersama diproduksi oleh kekuasaan sosial lewat praktik diskursus dan legitimasi. Ada dua poin yang penting, menurut van Dijk, yakni: kekuasaan dan akses. Sebagai lembaga yang memiliki otoritas penting dalam persoalan yang menyangkut urusan agama, MUI melalui program sertifikasi dai sebenarnaya juga telah melakukan tidakan persuasif dengan jalan mempengaruhi kondisi mental seperti kepercayaan, sikap, dan pengetahuan. Bahkan, MUI melakukan legitimasi kepada dai-dai yang sudah mengikuti program sertifikasi dai ini kredibelitasnya terjamin. MUI sebagai lembaga negara secara otomatis menjadi aparatus negara sekaligsu telah menjadi kelompok elit. Dari itu, wacana tentang sertifikasi dai mudah tersampaikan kepada khalayak sebab MUI mempunyai akses yang besar. Oleh karena itu, sebagaimana diungkap Van Dijk, mereka yang lebih berkuasa mempunyai kesempatan lebih besar untuk mempunyai akses pada media, dan kesempatan lebih besar untuk mempengaruhi kesadaran khalayak melalui kontrol atas topik dan isi wacana

\section{Kesimpulan}

Peneliti menggunakan teknik analisis wacana kritis model Van Dijk dan menemukan bahwa Prime Talk edisi Sertifikasi Dai, Melawan Radikalisasi membangun lima wacana yaitu akhir-akhir ini pesan-pesan agama seringkali disampaikan oleh penceramah-penceramah yang pengetahuan keagamaannya dangkal sehingga cenderung ekstrim; standarisasi dai-dai yang frendly terhadap NKRI; pada selanjutnya sertifikasi dai akan diberlakukan di seluruh Indonesai; Indonesia sudah lambat dalam sertifikasi dai; dan Aparat keamanan harus tanggap untuk menurunkan dai-dai yang intoleran.

Kekuatan Prime Talk tidak hanya terbatas pada pembentukan wacana, namun juga sampai pada tahap pendefinisian dan penempatan posisi partisipanpartisipan produksi wacana. Melalui pembentuk wacana di atas, Prime Talk memberikan definisi peran masyarakat, peran dai, peran MUI, dan peran Zilvia Iskandar sendiri. Peneliti menemukan bahwa produksi talk show yang dilakukan Mata Najwa tidak hanya untuk menggulirkan wacana, tetapi sekaligus untuk 
menjawab kebutuhan pasar, sehingga berujung untuk memantapkan NKRI sekaligus sebagai kepentingan ekonomi politik Prime Talk Mmetro Tv sendiri.

\section{Daftar Pustaka}

\section{Buku}

Abdullah, Amin. Etika dan Dialog Antar Agama: Perspektif Islam. Yogyakarta: Dian/Interfide. 1993.

Ali, Maulana Muhammad. Islamologi. Jakarta: Darul Kutub Islamiyah. 1997.

Badara, Arif. Analisis Wacana: Teori Metode, dan Penerapannya Pada Wacana Media. Jakarta: Kencana. 2012.

Eriyanto, Analisis Wacana: Pengantar Analisis Teks Media. Yogyakarta: LkiS, 2012.

HT, Faruk. Analisis Wacana: Dari Linguistik Sampai Dekonstruksi.Yogyakarta: Kanal. 2002).

Roberts, Richard H. Religion and the Transformations of Capitalism: Comparative Approaches. London and New York: Routledge. 1995.

Sagala, S. Administrasi Pendidikan Kontemporer. Bandung: Alfabeta. 2006.

Supriadi, D. Mengangkat Citra Dan Martabat Guru. Yogyakarta: Adicitra Karya Nusa. 2000.

\section{Jurnal}

Annur, Saipul. "Respon Masyarakat Terhadap Sertifikasi Ulama Di Kota Palembang," Medina-Te, Vol. 18 No. 1 Juni 2018.

Arina Rahmatika and Ninda Khoirullina, "Upaya Meneguhkan Islam Rahmatan Lil'alamin Melalui Majalah Bangkit," Jurnal Dakwah Dan Komunikasi, Vol. 5 no. 2, 2020.

Fakhroji, Moch. "Komodifikasi Agama Sebagai Masalah Dakwah," Jurnal Ilmu Dakwah, Vol. 5 No. 16 Juli-Desember 2010.

Huda, Miftahul "Komodifikasi Pesan Dakwah Pada Iklan Pertamina Versi Tabungan Terbaik Di Televisi," Jurnal Dakwah Dan Komunikasi, Vol. 3 No. 2, 2018.

Munib, Abd. "Framing Media Atas Pemberitaan Sertifikasi Dai," Jurnal Peurawi, Vol. 3 No. 2. Tahun 2020.

Rubawati, Efa. "Media Baru: Tantangan Dan Peluang Dakwah," Jurnal Studi Komunikasi, Vol. 2. Maret 2018.

Rustandi, Ridwan."Analisis Wacana Kritis Komodifikasi Dai dalam Program Televisi,"Communicatus, Volume 2 Nomor 2 Tahun 2018. 